\title{
Achievements and challenges in bioartificial kidney development
}

\author{
Farah Tasnim, Rensheng Deng, Min Hu, Sean Liour, Yao Li, Ming Ni, Jackie Y Ying, Daniele Zink*
}

\begin{abstract}
Bioartificial kidneys (BAKs) combine a conventional hemofilter in series with a bioreactor unit containing renal epithelial cells. The epithelial cells derived from the renal tubule should provide transport, metabolic, endocrinologic and immunomodulatory functions. Currently, primary human renal proximal tubule cells are most relevant for clinical applications. However, the use of human primary cells is associated with many obstacles, and the development of alternatives and an unlimited cell source is one of the most urgent challenges. BAKs have been applied in Phase I/II and Phase II clinical trials for the treatment of critically ill patients with acute renal failure. Significant effects on cytokine concentrations and long-term survival were observed. A subsequent Phase llb clinical trial was discontinued after an interim analysis, and these results showed that further intense research on BAK-based therapies for acute renal failure was required. Development of BAK-based therapies for the treatment of patients suffering from end-stage renal disease is even more challenging, and related problems and research approaches are discussed herein, along with the development of mobile, portable, wearable and implantable devices.
\end{abstract}

\section{Artificial kidneys}

Treatment with an artificial kidney is the most widely applied therapy for kidney failure. Substantial improvements have been made in artificial kidney technology during the past decades, such as with regard to membrane technology, dialysate composition, and medication to address side effects. Despite these improvements, the high rates of mortality of critically ill patients with acute renal failure (ARF), ranging between $50 \%$ and $70 \%$, did not change for several decades [1-5]. Also, the rates of morbidity and mortality of patients with end-stage renal disease (ESRD) receiving treatment with an artificial kidney remain high [6,7], and the survival advantage associated with renal transplantation is evident [8-12]. The problems associated with ESRD are increasing as the number of patients increases in industrialized countries, whereas the number of kidneys available for transplantation remains relatively low [6,7,13-15].

Which types of improvements of current therapies would be useful and which types of alternative therapies could be developed? It would definitely be useful to further improve artificial kidney technology to achieve a more efficient clearance of middle-sized uremic toxins

\footnotetext{
* Correspondence: dzink@ibn.a-star.edu.sg

Institute of Bioengineering and Nanotechnology, 31 Biopolis Way, The Nanos, Singapore 138669, Singapore
} continuous and ambulatory modes of treatment of larger groups of patients would be desirable.

Continuous treatment with artificial kidneys is usually only performed in cases of ARF, in which patients are hospitalized. Concerning ESRD, only those patients with peritoneal dialysis receive prolonged or continuous treatment, which is a minority $(<10 \%$, variable between different countries). The rest of the patients depend on traditional in-center hemodialysis, which is usually performed three times per week for several hours during daytime. This type of treatment not only greatly reduces the quality of life and is associated with high costs, but also leads to periodic accumulation of fluid, uremic toxins and metabolic wastes. Increasing evidence suggests that prolonged and/or more frequent therapies offer improvements in clinical outcomes and the quality of life, and might also be more cost-effective when performed at home [18-23]. Portable and wearable devices allow for a more normal lifestyle to be achieved and enable more frequent or continuous home-based therapies to be performed. A portable device for home hemodialysis that also allows for travel is now available [24-27]. A wearable artificial kidney is being developed, and successful human pilot studies have been performed 
[28-33]. This is currently one of the most exciting and promising developments in the field.

\section{Concepts and achievements in BAK development}

Portable or wearable artificial kidneys would only allow for a certain extent of volume and solute control and removal of some uremic toxins. However, the kidneys have many additional functions. These include reabsorption of glucose, amino acids and water, and excretion of xenobiotics, drugs and other organic compounds [34-38]. Furthermore, the kidneys regulate the concentrations of sodium, potassium, phosphorus and divalent cations, and the acid-base balance $[37,39,40]$. They control blood volume and pressure, and have important metabolic and endocrinologic functions [37,41,42]. The hormones produced by the kidneys include erythropoietin, renin, prostaglandins and 1,25-dihydroxy vitamin $\mathrm{D}_{3}$, which is also called calcitriol and is the most active form of vitamin $D$. The kidneys are also the major source of the growth factor bone morphogenetic protein (BMP)-7 in the adult body, which appears to be important for bone homeostasis [43-45]. In addition, the kidneys may perform immunomodulatory functions [46-50].

As these complex functions cannot be provided by artificial kidneys, it was suggested that renal cells be included in the devices, and the concept of bioartificial kidneys (BAKs) was first developed by Aebischer and co-workers in 1987 [51-55]. BAKs based on this concept combined a conventional hemofilter, mimicking glomerular functions, in series with a bioreactor containing renal tubule-derived cells, which should provide tubular functions. Epithelial cells derived from the proximal tubules are most interesting for BAK development, because they perform a wide variety of functions, including reabsorption and secretion $[34,35,37,38,40,41,56]$, as well as metabolic, endocrinologic $[37,39,41,42,57]$ and probably also immunomodulatory $[46-48,50]$ functions. The bioreactor unit seeded with proximal tubule-derived cells has also been called a renal tubule assist device (RAD) [58,59].

Research on BAKs has been performed mainly by two groups since the late 1990s: the group led by Akira Saito at the Tokai University School of Medicine, Kanagawa, Japan [60-71] and the group led by $\mathrm{H}$. David Humes at the University of Michigan, USA [58,59,72-79]. Additional work on BAKs with a RADtype bioreactor has been conducted by other groups $[80,81]$, also with the goal to develop a device that clears from the blood toxins such as digoxin using cells overexpressing multidrug-resistant protein [82-84]. More recent work has addressed the development of a bioartificial glomerulus using CD133+ endothelial progenitor cells [85], and there was a conceptual study that proposed a bioartificial nephronon-a-chip including glomerulus, proximal tubule and loop of Henle [86].

Clinical trials with BAKs have been performed by the group of H. David Humes and collaborators [76,78]. A Phase I/II clinical trial, which was performed with 10 critically ill patients with ARF, had shown that the device was sufficiently safe [78]. Any significant changes of parameters, which should be influenced by the human renal proximal tubule cells included in the device, could not be observed, and there were no significant changes in the $\mathrm{pH}$ of the ultrafiltrate or in 1,25-dihydroxy vitamin $D_{3}$ levels. About $90 \%$ of the glutathione passed the RAD. There were some changes in the levels of the five cytokines tested. The levels of granulocyte colony-stimulating factor, interleukin- 6 and interleukin-10 were significantly reduced in a subset of patients.

Subsequently, a multicenter, randomized, controlled, open-label Phase II clinical trial was performed in 2004 and 2005, which enrolled 58 critically ill patients with ARF [76]. 18 patients received continuous renal replacement therapy (CRRT), whereas 40 patients were treated using continuous venovenous hemofiltration (CVVH) and received additional treatment with a RAD. Patients were treated for up to $72 \mathrm{~h}$. The results showed effects on 28-day and 180-day survival, which were improved in patients receiving CVVH plus RAD treatment. Only the effects on long-term survival (180 days) were significant.

This study was revolutionary but was also heavily criticized. It was pointed out that the study was severely underpowered [87]. Amongst the various points of criticism raised was also the issue that it was difficult to understand how long-term survival could be improved when no significant short-term effects were observed, in particular when the treatment lasted at most for only $72 \mathrm{hr}$ [87]. A follow-up Phase IIb bridging study enrolling 53 patients was discontinued in 2006 after an interim analysis because it was not expected that the study would meet its efficacy goal (discussed in [76]).

The clinical trial was sponsored by RenaMed Biologics, Inc., a company co-founded by $\mathrm{H}$. David Humes. The company was founded in 1995 as Nephros Therapeutics, Inc. and changed its name in 2005. After suspension of the Phase IIb bridging study in 2006, RenaMed Biologics, Inc. was restructured and renamed Nephrion, Inc. in 2007. Nephrion Inc. is now called CytoPherx, Inc., and it is engaged in the commercialization of a selective cytopheretic inhibitory device $[88,89]$.

A first publication on this device [88] was based on the data from the Phase IIb clinical trial with BAKs, which had to be discontinued. Only the data from a control subgroup were evaluated for this study [88], and 
this control group received treatment with a sham noncell-containing (SCD) cartridge. Twelve of the 24 patients in this control group received systemic heparin anticoagulation, and the remaining 12 patients received regional citrate anticoagulation. The results indicated improved survival in the citrate-treated group (67\%, 90-day survival), whereas only $25 \%$ of the heparintreated patients survived after 90 days. The results have to be interpreted with care owing to the small numbers of patients, but they were in accordance with other observations suggesting improved survival with citrate anticoagulation as compared to heparin treatment [90]. The authors of the study on the selective cytopheretic inhibitory device [88] interpreted their results in a way that lymphocyte attachment to the "cytopheretic" membranes in the cell-free cartridge (commercial F40 hemofiltration cartridge; Fresenius AG, Bad Homburg, Germany) improved clinical outcomes.

Altogether the work and the results discussed above suggested that there were significant challenges with the cell-containing cartridges and BAKs in clinical trials. It would be useful to discuss and review the work conducted so far and the device design presented in the interest of advancing new concepts for future research.

\section{Renal cell types and growth substrates applied in BAKs}

What distinguishes a BAK from conventional hemofiltration devices is the bioreactor unit with renal cells. So far, BAK-related research has focused on renal proximal tubule-derived cells. Human primary renal proximal tubule cells (HPTCs) have been used in the clinical trials $[76,78]$. In contrast, most of the preceding experimental work and the animal studies performed by H. David Humes and co-workers have been performed with porcine primary renal proximal tubule cells $[58,59,74,75]$ (the earlier studies $[58,59]$ claimed that proximal tubule progenitor cells were used, although no evidence has been presented that a specific subfraction of progenitor cells had been isolated from the porcine kidneys). Also, the proximal tubule-like porcine cell line LLC-PK (Lewis lung cancer-porcine kidney 1 ) has been used frequently for BAK research $[51,52,54,62-65,67]$, and part of the work has been performed with other animal-derived cell lines, which were not always of proximal tubule origin, such as Madin-Darby canine kidney (MDCK) cells.

It is mandatory that the renal cells form a confluent differentiated epithelium sealed by tight junctions on the porous membranes of the device. If this does not occur, the cellular functions would be absent or compromised. Under such conditions, the entire BAK would only perform the functions of a normal hemofiltration device, with the undesired diffusion of ultrafiltrate components back into the blood in the bioreactor unit. The problem with using animal cells for BAK research is that animal cell lines and probably also primary animal cells would show different requirements for growth and differentiation from the primary human cells. This is obvious, for instance, with regard to the formation of differentiated epithelia on different membrane materials. Figure 1 shows hollow fiber membranes consisting of polyethersulfone/polyvinylpyrrolidone (PES/PVP), within which MDCK cells form a polarized epithelium with a welldeveloped brush border. No such results could be obtained with HPTCs, which would not grow and survive on PES/PVP, regardless of whether it was coated with an extracellular matrix (ECM) or not (M. Ni, J. C. M. Teo, M. S. bin Ibrahim, K. Zhang, F. Tasnim, P.-Y. Chow, D. Zink and J. Y. Ying, unpublished results). It was also found that HPTCs would not grow well on polysulfone (PSF) membranes or membranes consisting of PSF blended with a phospholipid polymer; membranes coated with a fibronectin ECM did not improve the situation [68]. In contrast, MDCK and LLC-PK 1 cells formed confluent monolayers on these materials, regardless of whether an ECM coating was present [68]. Furthermore, we found that HPTCs would not grow and survive on polysulfone/polyvinylpyrrolidone (PSF/ PVP) membranes, and in this case, cell performance could not be sufficiently improved by a single coating of a suitable ECM consisting of collagen IV (M. Ni, J. C. M. Teo, M. S. bin Ibrahim, K. Zhang, F. Tasnim, P.-Y. Chow, D. Zink and J. Y. Ying, unpublished results).

Commercial cartridges with hollow fiber membranes consisting of PSF/PVP have been applied in BAKs for animal studies and clinical trials, and cells were seeded after ECM coating [58,74-78]. In many cases, ECM coatings of either laminin or collagen IV were used, and systematic tests revealed that these were indeed the most suitable ECM components for applications with HPTCs [91]. However, the results discussed above show that cell performance was mainly influenced by the underlying membrane material, and a single ECM coating would not sufficiently improve cell performance.

Together, the findings suggested that PSF/PVP was not suitable for applications with HPTCs, which was the cell type used in clinical trials. The fact that most of the in vitro and in vivo work on BAKs was not performed with HPTCs, while HPTCs were then applied in clinical trials, might explain some of the problems experienced. It would be important to perform future in vitro and preclinical studies with exactly the same cell type that would be used in clinical trials.

\section{Improvement of HPTC performance, alternative cell types and growth factor-releasing BAKs}

An important question is whether HPTCs are indeed the most useful cell type for BAKs or whether other cell 


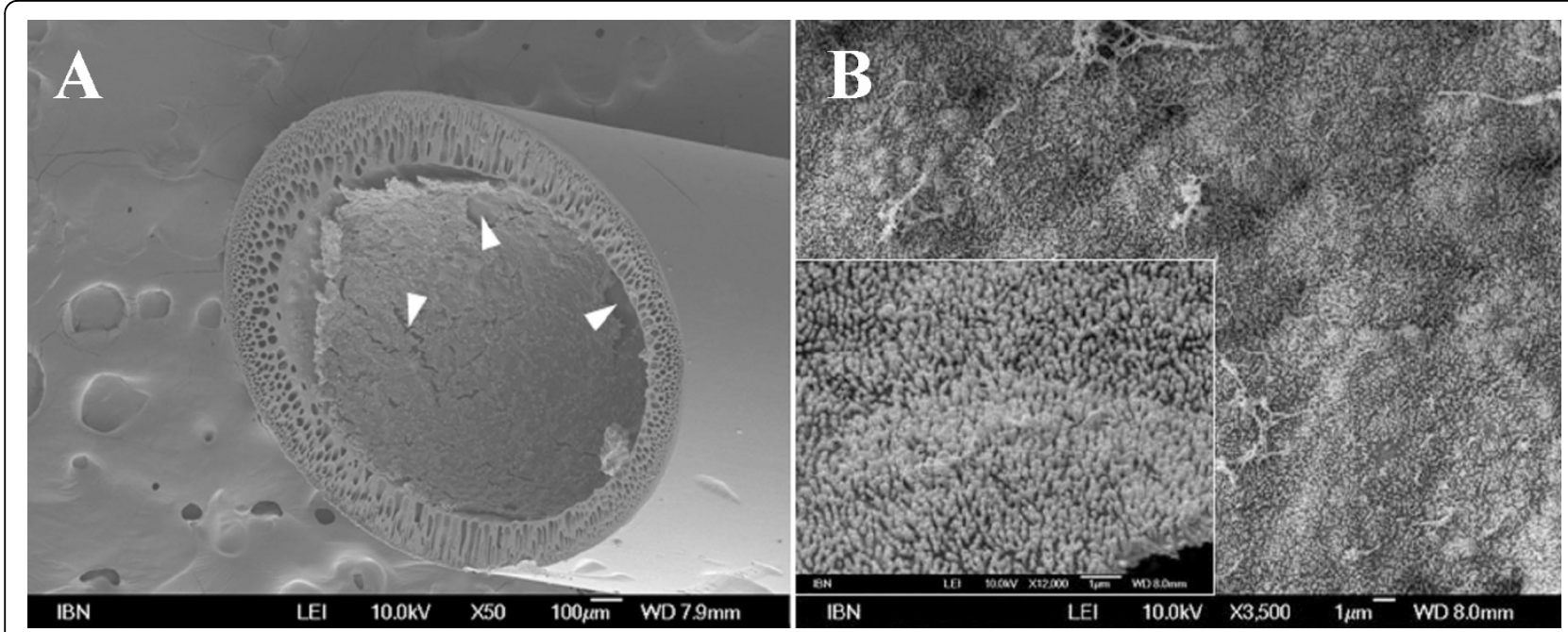

Figure 1 Madin-Darby canine kidney (MDCK) cells form a polarized epithelium on the inner surface of polyethersulfone/ polyvinylpyrrolidone (PES/PVP) hollow fiber membranes. (a) Confluent monolayer of MDCK cells on the inner surface of a PES/PVP hollow fiber membrane. Cracks in the monolayer (indicated by arrowheads) are artifacts resulting from sample preparation (scale bar $=100 \mu \mathrm{m})$. (b) Luminal surface of the MDCK cell layer on the inner surface of a PES/PVP hollow fiber membrane (scale bar $=1 \mu \mathrm{m}$ ). The cell surface is densely covered with microvilli. The inset in the lower left corner shows an enlargement of the microvilli-covered surface (scale bar $=1 \mu \mathrm{m})$. All images were obtained by scanning electron microscopy.

types might be more appropriate. HPTCs are obtained from nontransplantable human kidneys. Material from diseased kidneys would be suboptimal because, depending on the underlying condition, cell functions might be altered. Thus, it would be better to use only nondiseased kidneys that have been rejected for other reasons, although it might be difficult to obtain sufficient amounts of material. The limited cell source is indeed a serious problem, as the primary cells have a limited lifespan. As the membrane area of the bioreactor unit of one BAK should have a size of about 0.7-1.0 $\mathrm{m}^{2}$ $[70,76,78]$, it is questionable whether sufficient numbers of HPTCs can be obtained for the regular applications of BAKs and the commercialization of this approach.

Furthermore, primary proximal tubule cells show functional changes during passaging, and dedifferentiation as well as transdifferentiation processes occur [91-95]. This, together with the interdonor variability, makes standardization difficult; at the minimum, it would require extensive functional characterization of each cell batch at defined passage numbers.

In addition, recent results showed that HPTCs form spontaneously large and functional kidney tubules on 2D surfaces and within tubular substrates (Figure 2) [96]. The epithelium becomes disrupted during the process of tubule formation. Although such renal tubules generated in vitro in a gel-free system are very interesting for other applications, such as in vitro nephrotoxicology, their appearance in BAKs would compromise device functions and lead to clogging of the hollow fibers.
Interestingly, Humes and Cieslinski described the formation of renal tubules from primary rabbit proximal tubule cells on 2-D surfaces in 1992 [97]. However, this phenomenon, which is in our experience a serious obstacle in BAK development, was not further addressed by Humes and Cieslinski. One reason for this could be the finding that tubule formation on 2-D surfaces was dependent on supplementation with different factors, including transforming growth factor (TGF)- $\beta 1$ [97]. Thus, tubule formation would not occur spontaneously. However, we found that in vitro cultures of HPTCs expressed TGF- $\beta 1$ and did not depend on supplementation; this was in agreement with our observation that formation of renal tubules by HPTCs occurred spontaneously [96].

Recent results showed that inhibition of tubule formation by HPTCs could be achieved by either co-culturing of HPTCs with primary human umbilical vein endothelial cells or by supplementation with $1 \mathrm{nM}$ of BMP-7 (Tasnim et al., unpublished results). The latter finding was particularly interesting. BMP-7 (also called osteogenic protein (OP)-1) is a growth factor of the TGF- $\beta$ superfamily and counteracts TGF- $\beta 1$-induced effects [98-101]. The kidney is the major source of BMP-7 in the adult body, and BMP-7 appears to be important for bone homeostasis [43-45]. Animal experiments have shown that administration of BMP-7 improves kidney recovery in models of acute and chronic renal disease [44,100,102-107]. BMP-7 also has positive effects on vascular calcification and bone disease associated with 

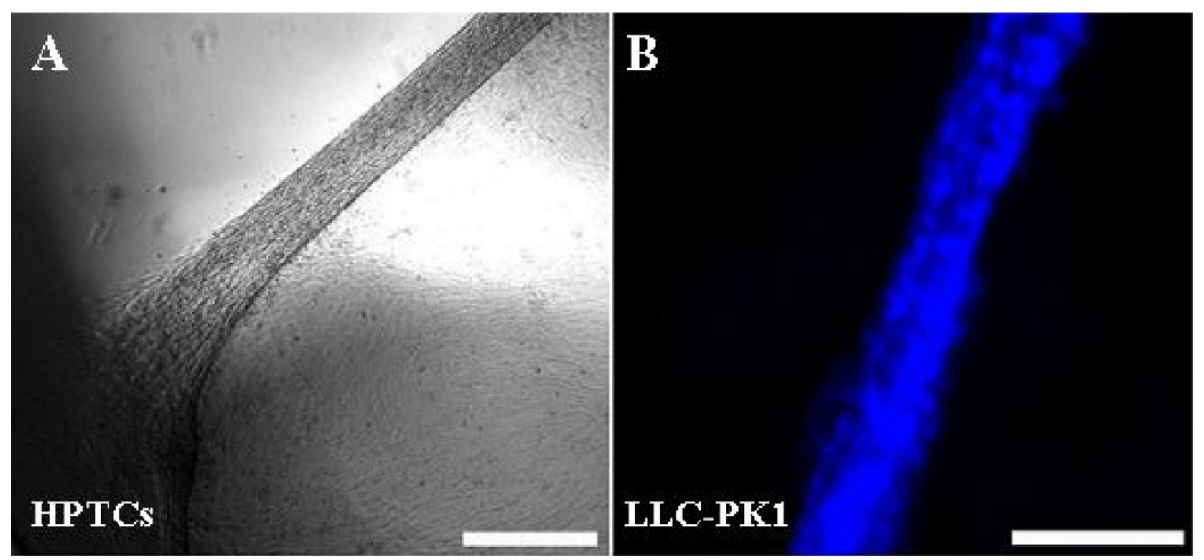

Figure 2 Renal tubules that have formed spontaneously on 2-D surfaces in vitro. Renal cells were cultivated on the bottom of the wells of multiwell plates for several days until spontaneous tubule formation occurred. (a) Part of a renal tubule formed by human primary renal proximal tubule cells (HPTCs). The left end of the tubule is attached to the edge of the well (dark rim in the lower left corner). The epithelium on the bottom of the well was partially disrupted during the process of tubule formation (area devoid of cells in the upper left corner). The image was obtained by bright field microscopy, and the appearance of areas with bright and dark illumination is due to optical effects close to the edge of the well and around the tubule. (b) Part of a renal tubule formed by LLC-PK ${ }_{1}$ cells. The cell nuclei were stained with 4', 6'diamidino-2'-phenylindole (DAPI, blue). The image was obtained by epifluorescence microscopy. Scale bars = (a) $400 \mu \mathrm{m}$ and (b) $100 \mu \mathrm{m}$.

chronic kidney failure in animal models [108-114]. Stryker Biotech is currently developing BMP-7-based treatments for kidney disease. It provides products consisting of a collagen sponge releasing human recombinant BMP-7 (OP-1 Putty and OP-1 Implant) for the treatment of bone disease.

Treatment of kidney disease would require systemic administration of BMP-7, and in this regard, the short serum half-life of the growth factor of about $30 \mathrm{~min}$ is a problem. Treatment based on frequent administration of BMP-7 to kidney patients would be associated with high costs. A BMP-7-releasing BAK, which delivers low concentrations of the growth factor to kidney patients during extended time periods (Figure 3), might be an elegant solution for these problems. BMP-7 could either be released in a controlled manner from the membranes or other parts of the device, using, for instance, microparticle technology. Alternatively, HPTCs, which normally do not express BMP-7, could be genetically engineered to achieve BMP-7 secretion. A third possibility would be the inclusion of additional renal cell types (e.g., distal tubule cells) that express endogenous BMP7. However, with the latter approach, it might be difficult to exactly control the amounts of BMP-7 released by the device. Apart from the beneficial effects on kidney patients treated with the BMP-7-releasing BAK, BMP-7 secretion within the device would also be expected to inhibit tubule formation and improve cell performance within the BAK. However, we would like to point out that the benefit of BMP-7 release by BAKs is still speculative at this point, and the discussion above reflects our personal view. It is also worth mentioning that secretion of active proteins into the bloodstream is one possible application of BAKs, and the use of BMP-7 is one possible example of such an application.

However, the question remains whether HPTCs, even if their performance can be improved, are indeed the best cell type for BAKs. Problems with the limited cell source, limited proliferative capacity, dedifferentiation, transdifferentiation and interdonor variability will remain. Also, for genetic engineering approaches, permanent cell lines would be preferable. For these reasons, Akira Saito and co-workers focused their work on cell lines, and the porcine cell line LLC-PK ${ }_{1}$ has been used in most of their studies. This cell line, which is frequently applied in in vitro nephrotoxicology, is very well characterized; as compared to other proximal tubulederived cell lines, LLC-PK 1 cells are relatively well differentiated [92]. However, the results of the work by Saito's group suggest that the passage of blood urea nitrogen (BUN) and creatinine when LLC-PK ${ }_{1}$ cells are used in a BAK is not appropriate for clinical applications [64], and the use of other cell types is suggested. Furthermore, multilayered overgrowth of LLC-PK ${ }_{1}$ cells in hollow fiber membranes was observed, which led to functional impairment after about 13 days [63]. Overgrowth could be inhibited with the mitogen-activated protein/extracellular signal-regulated kinase kinase inhibitor U0126 [65], but it was unclear what effects this inhibitor might have on kidney patients in BAK applications.

Recently, we have observed that LLC-PK ${ }_{1}$ cells also spontaneously formed renal tubules in gel-free cultures (Figure 2), and some of the multicellular structures 


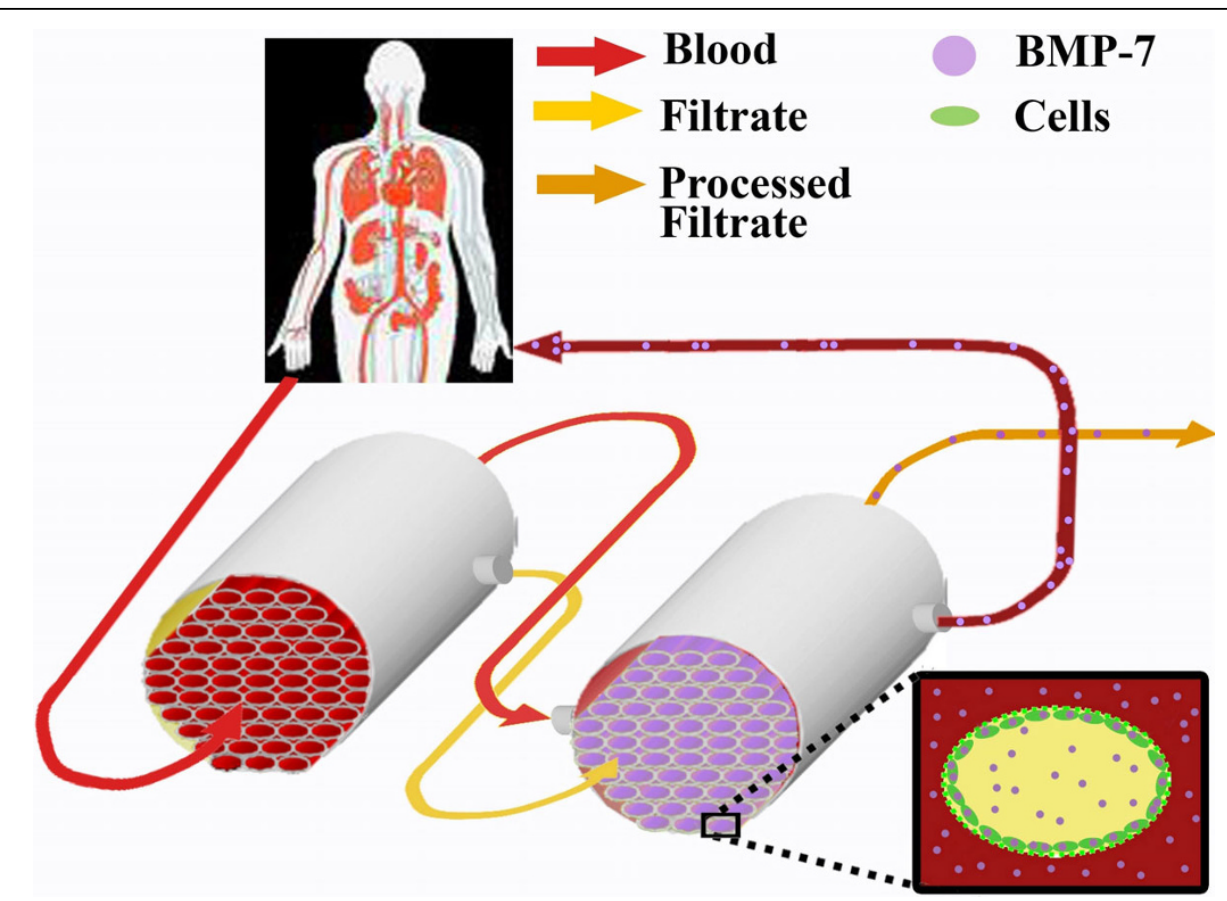

Figure 3 Schematic of a bone morphogenic protein (BMP)-7-producing bioartificial kidney (BAK). The patient's blood (red) first enters the hemofiltration unit (left), which contains hollow fiber membranes for ultrafiltration. The blood and the ultrafiltrate (yellow) leaving the hemofiltration unit then flow into the bioreactor unit (right), which contains hollow fiber membranes with an epithelium of renal cells (green) on the inner surfaces. The cells secrete BMP-7 (violet), which becomes enriched in the ultrafiltrate during processing and in the blood flowing on the outside of the hollow fiber membranes. The blood enriched in BMP-7 flows back into the patient, and the processed ultrafiltrate (orange) is discarded. An enlarged cross-section of a hollow fiber membrane from the bioreactor unit is shown in the lower right corner. The ultrafiltrate flows in the lumen of the hollow fiber membrane, and the blood flows on the outside. The inner surface of the hollow fiber membrane is covered with BMP-7-secreting renal cells, and BMP-7 becomes enriched in the ultrafiltrate and the blood in the bioreactor unit. BMP-7 in the ultrafiltrate would regulate HPTC performance, whereas BMP-7 in the bloodstream would be delivered to the patient.

observed by Saito's group [63,65] might have been generated by tubule-forming processes and might not just represent overgrowth. Apart from these specific problems with LLC-PK 1 cells, animal-derived cells are generally problematic due to (1) the concerns associated with approval for clinical applications and (2) their different physiology. Therefore, it would be preferable to apply human cells instead of porcine cells in BAKs, but are appropriate human cell lines available?

The first permanent human proximal tubule-derived cell lines have been generated in the $1990 \mathrm{~s}$ by using oncogenes $[115,116]$. These cell lines include the widely used HK-2 cells. HK-2 cells show some differentiated functions of proximal tubule cells, but are functionally and morphologically not equivalent to primary cells [91,116-118], and the use of oncogenes is associated with safety concerns. Drawbacks due to high and uncontrolled levels of oncogene expression have been addressed by using a temperature-sensitive mutant of the simian virus (SV) 40 large T antigen [119], also in combination with the human telomerase reverse transcriptase (hTert) gene [120] for the conditional immortalization of HPTCs.
Retroviral constructs were used in these studies, and the use of retroviral vectors, especially in combination with an oncogene, is associated with safety concerns in clinical applications. Also, the human proximal tubule-derived cell lines obtained did not express some important functional proteins, and further functional characterization would be required. In general, expression of important functional proteins or their mRNA is often markedly lower in renal cell lines than in primary cells, and this applies in particular to proximal tubule cells [121].

The SV40 T antigen has also been used in combination with hTert to generate reversibly immortalized HPTCs, taking advantage of the Cre/lox system [117]. The transgenes can be cut out when sufficient cell numbers have been obtained. The results showed that differentiated functions such as $\alpha$-methylglucopyranoside uptake (indicator for glucose transport) or $\gamma$-glutamyl transferase (GGT) activity were compromised in comparison to primary HPTCs, and the levels of activity observed in primary cells were not restored after removal of the transgenes. This might be due to stable epigenetic changes. 
Another approach to generate human proximal tubule-derived cell lines with improved properties for various applications is based on the expression of the hTert transgene only and does not involve oncogenes. The results suggested that expression of hTert alone was sufficient to achieve immortalization of HPTCs [118]. Characteristic features and functions of differentiated HPTCs did not appear to be severely compromised after immortalization. The hTert-expressing cells were obtained by using retroviral vectors, and this would be a safety concern in clinical applications. Also, the cells were not cloned after transduction, and thus the existing mixture of different immortalized cell clones might change over time. These issues should be addressed for applications in BAKs. It is worth mentioning that hTert-immortalized human proximal tubulederived cells as well as the cell lines mentioned above are very interesting for a variety of other applications such as in vitro nephrotoxicology.

Stem cell-based approaches are most attractive for achieving an unlimited and less variable cell source for BAKs. It has been shown that murine embryonic stem (ES) cells cultured in vitro can be induced to express markers specific for the intermediate mesoderm, from which the kidneys arise during embryonic development, by using a combination of retinoic acid, activin-A, and BMP-7 [122]. The treated ES cells appear to be primed to respond to inductive signals and to differentiate along the renal epithelial lineage, although no true renal epithelial cells have been obtained in vitro. Another recent study demonstrated the induction of markers specific for renal precursors using similar inducers applied to in vitro cultivated human ES cells [123].

Wnt signaling is important for the proper development of kidney tubules in mice [124,125], and improper stimulation of the canonical Wnt pathway plays a role in various types of human cystic kidney diseases [126]. It would be expected that Wnt signaling would be essential for the differentiation of renal precursor cells into epithelial renal tubule cells in vitro. Human mesenchymal stem cells differentiate into mature kidney cells, including epithelial renal tubule cells, in an organspecific environment in rodent embryos [127,128]. In vitro conditioned medium from injured proximal tubule cells induced epithelial differentiation of human adipose-derived adult mesenchymal stem cells [129]. Although the results suggest potential utility of stem cells in kidney bioengineering, further work is required to develop protocols for the differentiation of stem cells into mature human renal proximal tubule cells and other renal cell types in vitro. Currently, such cells are not available for applications in BAKs.

If stem cell-based approaches should be developed, the relevant legislation of those countries where the BAK is to be applied must be carefully considered. In this regard, the use of mesenchymal or other types of adult stem/progenitor cells (the presence of adult renal stem or progenitor cells is controversially discussed) is less problematic, as compared to the use of embryonic stem cells. Applications of induced pluripotent stem (iPS) cells might be most attractive, but the use of oncogenes and integrating viral vectors for reprogramming is associated with safety concerns. The recently developed iPS cells free of vectors and transgene sequences may provide a solution for this problem [130-134].

In conclusion, from those cell types currently available, HPTCs appear to be most appropriate for clinical applications. However, the use of HPTCs is associated with many problems, and it would be important to explore stem cell-based and other alternative approaches. Whatever cell type is selected in the future, it would be important to carefully examine exactly this cell type under the actual BAK conditions during the preclinical phase before advancing to clinical trials.

\section{Membranes}

As discussed above, commercial hemodialysis/hemofiltration cartridges with ECM-coated hollow fiber membranes consisting of PSF/PVP have been applied in BAKs, but such materials do not appear to be appropriate for applications with HPTCs. The PVP component appears to contribute to the problems in HPTC growth and survival (M. Ni, J. C. M. Teo, M. S. bin Ibrahim, K. Zhang, F. Tasnim, P.-Y. Chow, D. Zink and J. Y. Ying, unpublished results). Membranes consisting of pure PSF are hydrophobic, which leads to difficulties in the adhesion of hydrophobic serum proteins. Thus, to prevent protein adhesion, all modern PSF- or PES-based membranes for hemodialysis/hemofiltration contain hydrophilic additives, which is in most cases PVP [135]. Although these components improve the antifouling properties, it is not too surprising that highly sensitive primary cells do not perform well on nonadhesive membrane surfaces.

Ueda et al. suggested in 2005 the use of asymmetric membranes with one hemocompatible and one cytocompatible surface [68]. These authors described a membrane consisting of PSF blended with a phospholipid polymer, which was asymmetrically distributed between the skin and the sponge layer of the membrane. In a static in vitro test, platelets could only slightly adhere to the sponge layer surface, which had a higher content of the phospholipid polymer. MDCK and LLC-PK 1 cells formed confluent monolayers on the more adhesive skin layer [68]. However, this did not apply to HPTCs, and thus this type of membrane would not be appropriate for use with HPTCs. In general, it would be preferable to use the relatively rough sponge layer for cell growth and to expose the smooth skin layer to the blood. 
Ueda et al.'s development of improved asymmetric membranes with a hemocompatible surface and a cellcompatible surface represented a major advance in the field. This could be achieved not only by generating asymmetric distributions of membrane components, but also by asymmetric coating of the surfaces using antifouling agents such as polyethylene glycol on the bloodexposed side and adhesive coatings on the cell-exposed side. The development of dual-layered membranes with each layer composed of a different material would be interesting. Dual-layered hollow fiber membranes have been developed for gas separation and water purification $[136,137]$. Membrane materials that are currently employed in hemodialysis/hemofiltration with demonstrated hemocompatibility would be suitable for the blood-exposed layer. In addition, the surface of this blood-exposed layer could be conjugated to anticoagulants (e.g., heparin) to reduce the requirement for other conventional anticoagulation treatments.

The remaining challenge involves the selection of materials and coatings appropriate for the cell-exposed layer. Our recent findings revealed problems with HPTC survival and differentiation on a variety of commercially available membrane materials (M. Ni, J. C. M. Teo, M. S. bin Ibrahim, K. Zhang, F. Tasnim, P.-Y. Chow, D. Zink and J. Y. Ying, unpublished results). Various surface treatments and single ECM coatings did not lead to sufficient improvements. In contrast, after double coating of PES/PVP or PSF/PVP with 3,4-dihydroxy-L-phenylalanine (DOPA) and collagen IV, improvement of HPTC performance was observed and the cells formed confluent epithelia with tight junctions on the doublecoated PSF/PVP.

As PVP appeared to be problematic, other additives were tested. HPTCs formed confluent epithelia on membranes consisting of PSF blended with FullCure (FC) under bioreactor conditions. Single or double coating did not further improve cell performance on such PSF-FC membranes (Ni et al., unpublished results). The fact that PCF-FC membranes do not require any coating for applications with HPTCs makes this material very attractive.

Growth and differentiation of primary human cortical tubular epithelial cells were also observed on collagen IV-coated thin film and nanostructured materials [138]. The materials tested included silicon nanopore membranes. These membranes have monodisperse slitshaped nanopores and display greater selectivity at a given value of hydraulic permeability in comparison to conventional membranes with cylindrical polydispersed pores $[138,139]$. High hydraulic permeability would be particularly important for the development of miniaturized wearable or implantable devices.

\section{Challenges related to the development of portable, wearable and implantable devices}

Current BAKs are large and immobile. The development of portable, wearable or implantable devices would be highly desirable and has been suggested by different authors during the past 20 years $[53,62,70,140,141]$. Such devices would allow for prolonged or continuous treatment, which would be expected to have beneficial effects on the patients' health status. In addition, higher mobility would substantially improve the patients' quality of life. Also, given the high costs associated with incenter treatment of ESRD, the costs associated with in-center BAK therapy with immobile devices might be a serious obstacle.

Portable artificial kidneys are already available [24-27], and clinical trials with wearable artificial kidneys are currently underway [28-33]. Thus, the engineering problems associated with miniaturization of cell-free artificial kidneys seem to be challenging but solvable. A problem specifically related to BAKs is the viability and functional performance of the cell layer. Currently, it is unclear whether renal epithelial cells, which react highly sensitively in vitro to the environmental conditions [142-144], can be maintained in a viable and functional state when they are moved around in a mobile device. Mobility will be associated with mechanical stress, which easily damages renal epithelial cells [142-144]. If the cells are functionally compromised, their reabsorption rate will decline. Removal of an excessive volume of extracellular fluid in the hemofiltration unit without sufficient reabsorption in the bioreactor will lead rapidly to a critical condition. Furthermore, if the cell layer in the device should become leaky, uremic toxins from the ultrafiltrate will diffuse back into the bloodstream. Thus, in a mobile device, the cell cartridge must be embedded in a way that damage by mechanical stress and other environmental factors is minimized, and a miniaturized system for monitoring the cell functions and the integrity of the epithelium would be required. Such housing and monitoring systems have yet to be developed, and it is unclear how cells could be shielded from mechanical stress.

Another challenge is the development of new membrane and device materials with improved anticoagulation and antifouling properties. Currently, the lifetime of hemodialysis/hemofiltration membranes is only about $100 \mathrm{hr}$. Exchange of cartridges would be relatively easy when an extracorporeal device would be used. However, an extracorporeal circulation is associated with a high risk of infection, and on-site handling requires extremely well-trained and dexterous patients. Given these and other problems, an implantable device appears to be preferable. However, even if the lifetime of the 
membranes could be dramatically extended to several weeks or months, this would still mean frequent surgery for an implantable device. Even for a device with a housing and an exchangeable cassette that would be implanted close to the body surface [141], the situation might not be acceptable.

Apart from the unsolved problems with the lifetime of membranes, it is currently not clear for how long an intact epithelium can be maintained in the bioreactor unit. Differentiated epithelia formed by HPTCs can be maintained under optimized in vitro conditions in the laboratory for several weeks. The lifetime of the epithelium might be shorter under BAK conditions whereby not all of the parameters can be optimized for cell performance. Thus, it is expected that the cell cartridge would also require frequent exchange, and this would apply to mobile as well as to immobile devices. This raises again the issue of cell source, as it would be difficult to obtain sufficient number of primary cells from nontransplantable organs. Thus, as long as the cell sourcing problem is not resolved, regular long-term treatment of a large number of ESRD patients would not be feasible with immobile or mobile devices.

\section{Conclusions}

After 23 years of BAK research, there remain many challenges to be addressed. Given the problem of cell sourcing, the costs associated with in-center BAK treatment and the issues associated with mobile devices, the development of BAK-based therapies for ESRD patients would take many more years of intense research. The most straightforward path ahead may involve the development of immobile devices for the treatment of ARF. This was the approach followed by H. David Humes and co-workers, and the existing complications demonstrate that a great deal of further research would still be needed. In the future, it would be important to perform the experimental work with exactly the same cell type that would be used in clinical studies. Otherwise, it would be difficult to predict how the clinically relevant cell type would perform under the actual BAK conditions. Although currently HPTCs appear to be the most relevant cell type, primary cells are suboptimal, and this issue as well as the cell sourcing problem must be addressed. Also, it would be critical to design and synthesize novel membrane materials with cytocompatibility, antifouling and anticoagulation properties, as well as other features such as hydrodynamic permeability and selectivity. Progress in this multidisciplinary research area would provide a solid basis for the development of more advanced BAK-based therapies.

\section{Acknowledgements}

We thank Joscha Muck (Institute of Bioengineering and Nanotechnology (IBN), Singapore) for help with arranging the figures, and Kangyi Zhang (IBN, Singapore) and Mohammed Shahrudin bin Ibrahim (IBN, Singapore) for comments and discussions. This work is supported by the Institute of Bioengineering and Nanotechnology (Biomedical Research Council, Agency for Science, Technology and Research, Singapore).

\section{Abbreviations}

ARF: acute renal failure; BAK: bioartificial kidney; BMP-7: bone morphogenetic protein-7; BUN: blood urea nitrogen; $\mathrm{CWH}$ : continuous venovenous hemofiltration; CRRT: continuous renal replacement therapy; DAPI: 4', 6'diamidino-2'-phenylindole; DOPA: 3,4-dihydroxy-L-phenylalanine; ECM: extracellular matrix; ES: embryonic stem; ESRD: end-stage renal disease; FC: FullCure; GGT: $\gamma$-glutamyl transferase; HPTC: primary human renal proximal tubule cell; hTert: human telomerase reverse transcriptase; iPS: induced pluripotent stem; LLC-PK ${ }_{1}$ : Lewis lung cancer-porcine kidney 1; MDCK: Madin-Darby canine kidney; OP-1: osteogenic protein-1; PES:

polyethersulfone; PSF: polysulfone; PVP: polyvinylpyrrolidone; RAD: renal tubule assist device; SCD: sham non-cell containing; SV40: simian virus 40; TGF: transforming growth factor.

\section{Authors' contributions}

DZ drafted the manuscript, and the other authors critically revised it. RD, $\mathrm{MH}, \mathrm{FT}$ and $\mathrm{YL}$ contributed the figures. All authors read and approved the final manuscript.

\section{Competing interests}

The authors declare that they have no competing interests.

Received: 1 June 2010 Accepted: 10 August 2010

Published: 10 August 2010

\section{References}

1. Du Cheyron D, Bouchet B, Parienti JJ, Ramakers M, Charbonneau P: The attributable mortality of acute renal failure in critically ill patients with liver cirrhosis. Intensive Care Med 2005, 31:1693-1699.

2. Mehta RL, Chertow GM: Acute renal failure definitions and classification: time for change? J Am Soc Nephrol 2003, 14:2178-2187.

3. Silvester W, Bellomo R, Cole L: Epidemiology, management, and outcome of severe acute renal failure of critical illness in Australia. Crit Care Med 2001, 29:1910-1915.

4. Ympa YP, Sakr Y, Reinhart K, Vincent JL: Has mortality from acute renal failure decreased? A systematic review of the literature. Am J Med 2005, 118:827-832.

5. Cheung CM, Ponnusamy A, Anderton JG: Management of Acute Renal Failure in the Elderly Patient: A Clinician's Guide. Drugs Aging 2008, 25:455-476.

6. U. S. Renal Data System: USRDS 2008 Annual Data Report: Atlas of Chronic Kidney Disease and End-Stage Renal Disease in the United States National Institutes of Health, National Institute of Diabetes and Digestive and Kidney Diseases, Bethesda, MD 2008.

7. U. S. Renal Data System: USRDS 2009 Annual Data Report: Atlas of Chronic Kidney Disease and End-Stage Renal Disease in the United States National Institutes of Health, National Institute of Diabetes and Digestive and Kidney Diseases, Bethesda, MD 2009.

8. Bayat S, Kessler M, Briancon S, Frimat L: Survival of transplanted and dialysed patients in a French region with focus on outcomes in the elderly. Nephrol Dial Transplant 2010, 25:292-300.

9. McDonald SP, Russ GR: Survival of recipients of cadaveric kidney transplants compared with those receiving dialysis treatment in Australia and New Zealand, 1991-2001. Nephrol Dial Transplant 2002, 17:2212-2219. 
10. Oniscu GC, Brown H, Forsythe JL: Impact of cadaveric renal transplantation on survival in patients listed for transplantation. J Am Soc Nephrol 2005, 16:1859-1865.

11. Rabbat CG, Thorpe KE, Russell JD, Churchill DN: Comparison of mortality risk for dialysis patients and cadaveric first renal transplant recipients in Ontario, Canada. J Am Soc Nephrol 2000, 11:917-922.

12. Wolfe RA, Ashby VB, Milford EL, Ojo AO, Ettenger RE, Agodoa LY, Held PJ, Port FK: Comparison of mortality in all patients on dialysis, patients on dialysis awaiting transplantation, and recipients of a first cadaveric transplant. N Engl J Med 1999, 341:1725-1730.

13. Lin S: Nephrology in China: a great mission and momentous challenge. Kidney Int Suppl 2003, 83:S108-S110.

14. Rutkowski B: Changing pattern of end-stage renal disease in central and eastern Europe. Nephrol Dial Transplant 2000, 15:156-160.

15. Vathsala A: Twenty-five facts about kidney disease in Singapore: in remembrance of World Kidney Day. Ann Acad Med Singapore 2007, 36:157-160.

16. Tattersall J: Clearance of beta-2-microglobulin and middle molecules in haemodiafiltration. Hemodiafiltration Basel: KargerRonco C, Canaud B, Aljama P 2007, 158:201-209.

17. Thomas G, Jaber BL: Convective therapies for removal of middle molecular weight uremic toxins in end-stage renal disease: a review of the evidence. Semin Dial 2009, 22:610-614.

18. Bayliss G, Danziger J: Nocturnal versus conventional haemodialysis: some current issues. Nephrol Dial Transplant 2009, 24:3612-3617.

19. Klarenbach S, Manns B: Economic evaluation of dialysis therapies. Semin Nephrol 2009, 29:524-532.

20. Kliger AS: More intensive hemodialysis. Clin J Am Soc Nephrol 2009, 4(Suppl 1):S121-S124.

21. Lockridge RS Jr, Pipkin M: Short and long nightly hemodialysis in the United States. Hemodial Int 2008, 12(Suppl 1):S48-S50.

22. Pierratos A, Ouwendyk M, Francoeur R, Vas S, Raj DS, Ecclestone AM, Langos V, Uldall R: Nocturnal hemodialysis: three-year experience. J Am Soc Nephrol 1998, 9:859-868.

23. Uldall R, Ouwendyk M, Francoeur R, Wallace L, Sit W, Vas S, Pierratos A: Slow nocturnal home hemodialysis at the Wellesley Hospital. Adv Ren Replace Ther 1996, 3:133-136.

24. Jaber BL, Finkelstein FO, Glickman JD, Hull AR, Kraus MA, Leypoldt JK, Liu J, Gilbertson D, McCarthy J, Miller BW, Moran J, Collins AJ, FREEDOM Study Group: Scope and design of the Following Rehabilitation, Economics and Everyday-Dialysis Outcome Measurements (FREEDOM) Study. Am J Kidney Dis 2009, 53:310-320.

25. Kohn OF, Coe FL, Ing TS: Solute kinetics with short-daily home hemodialysis using slow dialysate flow rate. Hemodial Int 2010, 14:39-46.

26. Kraus M, Burkart J, Hegeman R, Solomon R, Coplon N, Moran J: A comparison of center-based vs. home-based daily hemodialysis for patients with end-stage renal disease. Hemodial Int 2007, 11:468-477.

27. Scott A: Portable home hemodialysis for kidney failure. Issues Emerg Health Technol 2007, 108:1-4

28. Davenport A, Gura V, Ronco C, Beizai M, Ezon C, Rambod E: A wearable haemodialysis device for patients with end-stage renal failure: a pilot study. Lancet 2007, 370:2005-2010.

29. Gura V, Davenport A, Beizai $M$, Ezon $C$, Ronco $C$ : $\beta_{2}$-microglobulin and phosphate clearances using a wearable artificial kidney: a pilot study. Am J Kidney Dis 2009, 54:104-111.

30. Gura V, Macy AS, Beizai M, Ezon C, Golper TA: Technical breakthroughs in the wearable artificial kidney (WAK). Clin J Am Soc Nephrol 2009, 4:1441-1448.

31. Gura V, Ronco C, Davenport A: The wearable artificial kidney, why and how: from holy grail to reality. Semin Dial 2009, 22:13-17.

32. Gura V, Ronco C, Nalesso F, Brendolan A, Beizai M, Ezon C, Davenport A Rambod E: A wearable hemofilter for continuous ambulatory ultrafiltration. Kidney Int 2008, 73:497-502.

33. Ronco C, Davenport A, Gura V: A wearable artificial kidney: dream or reality? Nat Clin Pract Nephrol 2008, 4:604-605

34. Anzai $N$, Jutabha $P$, Kanai $Y$, Endou $H$ : Integrated physiology of proximal tubular organic anion transport. Curr Opin Nephrol Hypertens 2005 14:472-479.

35. Lee YJ, Lee YJ, Han $\mathrm{HJ}$ : Regulatory mechanisms of $\mathrm{Na}^{+}$/glucose cotransporters in renal proximal tubule cells. Kidney Int Supp/ 2007, 72 S27-S35.
36. Mount DB, Kwon CY, Zandi-Nejad K: Renal urate transport. Rheum Dis Clin North Am 2006, 32:313-331, vi.

37. Wilson CO, Block JH, Gisvold O, Beale JM: Wilson and Gisvold's textbook of organic medicinal and pharmaceutical chemistry Philadelphia: Lippincott Williams and Wilkins, 112004

38. Wright $\mathrm{SH}$ : Role of organic cation transporters in the renal handling of therapeutic agents and xenobiotics. Toxicol Appl Pharmacol 2005 , 204:309-319.

39. Curthoys NP, Godfrey SS: Properties of rat kidney glutaminase enzymes and their role in renal ammoniagenesis. Curr Probl Clin Biochem 1976, 6:346-356.

40. Soleimani $\mathrm{M}: \mathrm{Na}^{+}: \mathrm{HCO}_{3}{ }^{-}$cotransporters (NBC): expression and regulation in the kidney. J Nephrol 2002, 15(Suppl 5):S32-S40.

41. Brenner BM: Brenner and Rector's The Kidney Philadelphia: Saunders Elsevier, 82008.

42. Fraser DR, Kodicek E: Unique biosynthesis by kidney of a biological active vitamin D metabolite. Nature 1970, 228:764-766.

43. Gould SE, Day M, Jones SS, Dorai H: BMP-7 regulates chemokine, cytokine, and hemodynamic gene expression in proximal tubule cells. Kidney Int 2002, 61:51-60

44. Simic P, Vukicevic S: Bone morphogenetic proteins in development and homeostasis of kidney. Cytokine Growth Factor Rev 2005, 16:299-308.

45. Simon M, Maresh JG, Harris SE, Hernandez JD, Arar M, Olson MS, Abboud HE: Expression of bone morphogenetic protein-7 mRNA in normal and ischemic adult rat kidney. Am J Physiol 1999, 276:F382-F389.

46. Boswell RN, Yard BA, Schrama E, van Es LA, Daha MR, van der Woude FJ: Interleukin 6 production by human proximal tubular epithelial cells in vitro: analysis of the effects of interleukin- $1 \alpha$ (IL-1 $1 \alpha)$ and other cytokines. Nephrol Dial Transplant 1994, 9:599-606.

47. Prodjosudjadi W, Gerritsma JS, Klar-Mohamad N, Gerritsen AF, Bruijn JA, Daha MR, van Es LA: Production and cytokine-mediated regulation of monocyte chemoattractant protein-1 by human proximal tubular epithelial cells. Kidney Int 1995, 48:1477-1486.

48. Van Kooten C, Woltman AM, Daha MR: Immunological function of tubular epithelial cells: the functional implications of CD40 expression. Exp Nephrol 2000, 8:203-207.

49. Wahl P, Schoop R, Bilic G, Neuweiler J, Le Hir M, Yoshinaga SK, Wuthrich RP: Renal tubular epithelial expression of the costimulatory molecule B7RP-1 (inducible costimulator ligand). J Am Soc Nephrol 2002, 13:1517-1526.

50. Wuthrich RP, Glimcher LH, Yui MA, Jevnikar AM, Dumas SE, Kelley VE: MHC class II, antigen presentation and tumor necrosis factor in renal tubular epithelial cells. Kidney Int 1990, 37:783-792.

51. Aebischer P, Ip TK, Panol G, Galletti PM: The bioartificial kidney: progress towards an ultrafiltration device with renal epithelial cells processing Life Support Syst 1987, 5:159-168.

52. Ip TK, Aebischer P, Galletti PM: Cellular control of membrane permeability. Implications for a bioartificial renal tubule. ASAIO Trans 1988, 34:351-355.

53. Ip TK, Aebischer P: Renal epithelial-cell-controlled solute transport across permeable membranes as the foundation for a bioartificial kidney. Artif Organs 1989, 13:58-65.

54. Uludag $H$, Ip TK, Aebischer P: Transport functions in a bioartificial kidney under uremic conditions. Int J Artif Organs 1990, 13:93-97.

55. Uludag H, Panol G, Aebischer P: Control of water flux in a bioartificial kidney. ASAIO Trans 1989, 35:523-527.

56. Berndt WO: The role of transport in chemical nephrotoxicity. Toxicol Pathol 1998, 26:52-57.

57. Curthoys NP: Role of gamma-glutamyltranspeptidase in the renal metabolism of glutathione. Miner Electrolyte Metab 1983, 9:236-245.

58. Humes HD, Buffington DA, Mackay SM, Funke AJ, Weitzel WF: Replacement of renal function in uremic animals with a tissue-engineered kidney. Nat Biotechnol 1999, 17:451-455.

59. Humes HD, Mackay SM, Funke AJ, Buffington DA: Tissue engineering of a bioartificial renal tubule assist device: in vitro transport and metabolic characteristics. Kidney Int 1999, 55:2502-2514.

60. Fujita Y, Kakuta T, Asano M, Itoh J, Sakabe K, Tokimasa T, Saito A: Evaluation of $\mathrm{Na}^{+}$active transport and morphological changes for bioartificial renal tubule cell device using Madin-Darby canine kidney cells. Tissue Eng 2002, 8:13-24

61. Saito A, Aung T, Sekiguchi K, Sato Y, Vu DM, Inagaki M, Kanai G, Tanaka R, Suzuki $H$, Kakuta T: Present status and perspectives of bioartificial kidneys. J Artif Organs 2006, 9:130-135. 
62. Fujita Y, Terashima M, Kakuta T, Itoh J, Tokimasa T, Brown D, Saito A: Transcellular water transport and stability of expression in aquaporin 1transfected LLC-PK1 cells in the development of a portable bioartificial renal tubule device. Tissue Eng 2004, 10:711-722.

63. Ozgen N, Terashima M, Aung T, Sato Y, Isoe C, Kakuta T, Saito A: Evaluation of long-term transport ability of a bioartificial renal tubule device using LLC-PK1 cells. Nephrol Dial Transplant 2004, 19:2198-2207.

64. Terashima M, Fujita Y, Sugano K, Asano M, Kagiwada N, Sheng Y, Nakamura S, Hasegawa A, Kakuta T, Saito A: Evaluation of water and electrolyte transport of tubular epithelial cells under osmotic and hydraulic pressure for development of bioartificial tubules. Artif Organs 2001, 25:209-212.

65. Inagaki M, Yokoyama TA, Sawada K, Duc VM, Kanai G, Lu J, Kakuta T, Saito A: Prevention of LLC-PK 1 cell overgrowth in a bioartificial renal tubule device using a MEK inhibitor, U0126. J Biotechnol 2007, 132:57-64

66. Kanai N, Fujita Y, Kakuta T, Saito A: The effects of various extracellular matrices on renal cell attachment to polymer surfaces during the development of bioartificial renal tubules. Artif Organs 1999, 23:114-118.

67. Sato Y, Terashima M, Kagiwada N, Tun T, Inagaki M, Kakuta T, Saito A: Evaluation of proliferation and functional differentiation of LLC-PK1 cells on porous polymer membranes for the development of a bioartificial renal tubule device. Tissue Eng 2005, 11:1506-1515.

68. Ueda H, Watanabe J, Konno T, Takai M, Saito A, Ishihara K: Asymmetrically functional surface properties on biocompatible phospholipid polymer membrane for bioartificial kidney. J Biomed Mater Res A 2006, 77:19-27.

69. Saito A: Development of bioartificial kidneys. Nephrology (Carlton) 2003, 8(Suppl):S10-S15.

70. Saito A: Research into the development of a wearable bioartificial kidney with a continuous hemofilter and a bioartificial tubule device using tubular epithelial cells. Artif Organs 2004, 28:58-63.

71. Saito A, Aung T, Sekiguchi K, Sato Y: Present status and perspective of the development of a bioartificial kidney for chronic renal failure patients. Ther Apher Dial 2006, 10:342-347.

72. Mackay SM, Funke AJ, Buffington DA, Humes HD: Tissue engineering of a bioartificial renal tubule. ASAIO J 1998, 44:179-183.

73. Humes HD, Mackay SM, Funke AJ, Buffington DA: Acute renal failure: growth factors, cell therapy, and gene therapy. Proc Assoc Am Physicians 1997, 109:547-557.

74. Fissell WH, Lou L, Abrishami S, Buffington DA, Humes HD: Bioartificial kidney ameliorates gram-negative bacteria-induced septic shock in uremic animals. J Am Soc Nephrol 2003, 14:454-461.

75. Fissell WH, Dyke DB, Weitzel WF, Buffington DA, Westover AJ, MacKay SM, Gutierrez JM, Humes HD: Bioartificial kidney alters cytokine response and hemodynamics in endotoxin-challenged uremic animals. Blood Purif 2002, 20:55-60.

76. Tumlin J, Wali R, Williams W, Murray P, Tolwani AJ, Vinnikova AK, Szerlip HM, Ye J, Paganini EP, Dworkin L, Finkel KW, Kraus MA, Humes HD: Efficacy and safety of renal tubule cell therapy for acute renal failure. $J$ Am Soc Nephrol 2008, 19:1034-1040.

77. Humes HD, Fissell WH, Weitzel WF, Buffington DA, Westover AJ, Mackay SM, Gutierrez JM: Metabolic replacement of kidney function in uremic animals with a bioartificial kidney containing human cells. Am J Kidney Dis 2002, 39:1078-1087.

78. Humes HD, Weitzel WF, Bartlett RH, Swaniker FC, Paganini EP, Luderer JR, Sobota J: Initial clinical results of the bioartificial kidney containing human cells in ICU patients with acute renal failure. Kidney Int 2004, 66:1578-1588

79. Song $J H$, Humes HD: The bioartificial kidney in the treatment of acute kidney injury. Curr Drug Targets 2009, 10:1227-1234.

80. Dong $X$, Chen J, He Q, Yang Y, Zhang W: Construction of bioartificial renal tubule assist device in vitro and its function of transporting sodium and glucose. J Huazhong Univ Sci Technolog Med Sci 2009, 29:517-521.

81. Huijuan M, Xiaoyun W, Xumin Y, Hengjin W, Xia S: Effect of continuous bioartificial kidney therapy on porcine multiple organ dysfunction syndrome with acute renal failure. ASAIO J 2007, 53:329-334.

82. Tsuruoka S, Nishiki K, Sugimoto K, Suzuki M, Imai M, Fujimura A: Specific therapy of digoxin intoxication in dogs by hybrid kidney overexpressing multidrug resistance protein. Kidney Int 2002, 62:1332-1337.

83. Tsuruoka S, Nishiki K, Wakaumi M, Wang N, Yamamoto $H_{\text {, Ando }} \mathrm{H}_{\text {, Imai }} \mathrm{M}$, Fujimura A: Treatment of digoxin intoxication model by hybrid-kidney with hollowfibre module for clinical haemodialysis. Nephrol Dial Transplant 2004, 19:1339-1340.

84. Tsuruoka S, Sugimoto Kl, Ueda K, Suzuki M, Imai M, Fujimura A: Removal of digoxin and doxorubicin by multidrug resistance protein-overexpressed cell culture in hollow fiber. Kidney Int 1999, 56:154-163.

85. Vu DM, Masuda H, Yokoyama TA, Fujimura S, Kobori M, Ito R, Sawada K, Saito A, Asahara T: CD133+ endothelial progenitor cells as a potential cell source for a bioartificial glomerulus. Tissue Eng Part A 2009, 15:3173-3182.

86. Weinberg E, Kaazempur-Mofrad M, Borenstein J: Concept and computational design for a bioartificial nephron-on-a-chip. Int J Artif Organs 2008, 31:508-514.

87. Chertow GM, Waikar SS: Toward the promise of renal replacement therapy. J Am Soc Nephrol 2008, 19:839-840.

88. Humes HD, Sobota JT, Ding F, Song JH: A selective cytopheretic inhibitory device to treat the immunological dysregulation of acute and chronic renal failure. Blood Purif 2010, 29:183-190.

89. Song JH, Humes HD: Renal cell therapy and beyond. Semin Dial 2009, 22:603-609.

90. Oudemans-van Straaten HM, Bosman RJ, Koopmans M, van der Voort PH, Wester JP, van der Spoel JI, Dijksman LM, Zandstra DF: Citrate anticoagulation for continuous venovenous hemofiltration. Crit Care Med 2009, 37:545-552.

91. Zhang H, Tasnim F, Ying JY, Zink D: The impact of extracellular matrix coatings on the performance of human renal cells applied in bioartificial kidneys. Biomaterials 2009, 30:2899-2911.

92. Bach PH, Obatomi DK, Brant S: In vitro methods for nephrotoxicity screening and risk assessment. In vitro methods in pharmaceutical research San Diego: Academic PressCastell JV, Gómez-Lechón MJ 1997, 55-101.

93. Vesey DA, Qi W, Chen X, Pollock CA, Johnson DW: Isolation and primary culture of human proximal tubule cells. Methods Mol Biol 2009, 466:19-24.

94. Weiland C, Ahr HJ, Vohr HW, Ellinger-Ziegelbauer $\mathrm{H}$ : Characterization of primary rat proximal tubular cells by gene expression analysis. Toxicol In Vitro 2007, 21:466-491.

95. Verhulst A, Sayer R, De Broe ME, D'Haese PC, Brown CD: Human proxima tubular epithelium actively secretes but does not retain rosuvastatin. Mol Pharmacol 2008, 74:1084-1091.

96. Zhang H, Lau SF, Heng BF, Teo PY, Alahakoon PK, Ni M, Tasnim F, Ying JY, Zink D: Generation of easily accessible human kidney tubules on twodimensional surfaces in vitro. J Cell Mol Med 2010.

97. Humes HD, Cieslinski DA: Interaction between growth factors and retinoic acid in the induction of kidney tubulogenesis in tissue culture. Exp Cell Res 1992, 201:8-15.

98. Wang $S$, Hirschberg R: BMP7 antagonizes TGF- $\beta$-dependent fibrogenesis in mesangial cells. Am J Physiol Renal Physiol 2003, 284:F1006-F1013.

99. Wang $\mathrm{S}$, Hirschberg R: Bone morphogenetic protein-7 signals opposing transforming growth factor $\beta$ in mesangial cells. J Biol Chem 2004 279:23200-23206.

100. Zeisberg M, Hanai J, Sugimoto $H$, Mammoto $T$, Charytan D, Strutz F, Kalluri R: BMP-7 counteracts TGF- $\beta 1$-induced epithelial-to-mesenchymal transition and reverses chronic renal injury. Nat Med 2003, 9:964-968.

101. Flier SN, Tanjore H, Kokkotou EG, Sugimoto $H$, Zeisberg M, Kalluri R: Identification of epithelial to mesenchymal transition as a novel source of fibroblasts in intestinal fibrosis. J Biol Chem 2010, 285:20202-20212.

102. Hruska KA, Guo G, Wozniak M, Martin D, Miller S, Liapis H, Loveday K, Klahr S, Sampath TK, Morrissey J: Osteogenic protein-1 prevents renal fibrogenesis associated with ureteral obstruction. Am J Physiol Renal Physiol 2000, 279:F130-F143.

103. Morrissey J, Hruska K, Guo G, Wang S, Chen Q, Klahr S: Bone morphogenetic protein-7 improves renal fibrosis and accelerates the return of renal function. J Am Soc Nephrol 2002, 13(Suppl 1):S14-S21.

104. Wang S, Chen Q, Simon TC, Strebeck F, Chaudhary L, Morrissey J, Liapis H, Klahr S, Hruska KA: Bone morphogenic protein-7 (BMP-7), a novel therapy for diabetic nephropathy. Kidney Int 2003, 63:2037-2049.

105. Zeisberg M, Bottiglio C, Kumar N, Maeshima Y, Strutz F, Muller GA, Kalluri R: Bone morphogenic protein-7 inhibits progression of chronic renal fibrosis associated with two genetic mouse models. Am J Physiol Renal Physiol 2003, 285:F1060-F1067.

106. Zeisberg M, Kalluri R: Reversal of experimental renal fibrosis by BMP7 provides insights into novel therapeutic strategies for chronic kidney disease. Pediatr Nephrol 2008, 23:1395-1398. 
107. Vukicevic S, Basic V, Rogic D, Basic N, Shih MS, Shepard A, Jin D, Dattatreyamurty B, Jones W, Dorai H, Ryan S, Griffiths D, Maliakal J, Jelic M, Pastorcic M, Stavljenic A, Sampath TK: Osteogenic protein-1 (bone morphogenetic protein-7) reduces severity of injury after ischemic acute renal failure in rat. J Clin Invest 1998, 102:202-214.

108. Davies MR, Lund RJ, Hruska KA: BMP-7 is an efficacious treatment of vascular calcification in a murine model of atherosclerosis and chronic renal failure. J Am Soc Nephrol 2003, 14:1559-1567.

109. Davies MR, Lund RJ, Mathew S, Hruska KA: Low turnover osteodystrophy and vascular calcification are amenable to skeletal anabolism in an animal model of chronic kidney disease and the metabolic syndrome. $J$ Am Soc Nephrol 2005, 16:917-928.

110. Gonzalez EA, Lund RJ, Martin KJ, McCartney JE, Tondravi MM, Sampath TK, Hruska KA: Treatment of a murine model of high-turnover renal osteodystrophy by exogenous BMP-7. Kidney Int 2002, 61:1322-1331.

111. Hruska KA, Mathew S, Davies MR, Lund RJ: Connections between vascular calcification and progression of chronic kidney disease: therapeutic alternatives. Kidney Int Suppl 2005, S142-S151.

112. Hruska KA, Saab G, Chaudhary LR, Quinn CO, Lund RJ, Surendran K: Kidneybone, bone-kidney, and cell-cell communications in renal osteodystrophy. Semin Nephrol 2004, 24:25-38.

113. Li T, Surendran K, Zawaideh MA, Mathew S, Hruska KA: Bone morphogenetic protein 7: a novel treatment for chronic renal and bone disease. Curr Opin Nephrol Hypertens 2004, 13:417-422.

114. Mathew S, Davies M, Lund R, Saab G, Hruska KA: Function and effect of bone morphogenetic protein-7 in kidney bone and the bone-vascular links in chronic kidney disease. Eur J Clin Invest 2006, 36(Suppl 2):43-50.

115. Ryan MJ, Johnson G, Kirk J, Fuerstenberg SM, Zager RA, Torok-Storb B: HK2: an immortalized proximal tubule epithelial cell line from normal adult human kidney. Kidney Int 1994, 45:48-57.

116. Racusen LC, Monteil C, Sgrignoli A, Lucskay M, Marouillat S, Rhim JG, Morin JP: Cell lines with extended in vitro growth potential from human renal proximal tubule: characterization, response to inducers, and comparison with established cell lines. J Lab Clin Med 1997, 129:318-329.

117. Kowolik CM, Liang S, Yu Y, Yee JK: Cre-mediated reversible immortalization of human renal proximal tubular epithelial cells. Oncogene 2004, 23:5950-5957.

118. Wieser M, Stadler G, Jennings P, Streubel B, Pfaller W, Ambros P, Riedl C, Katinger H, Grillari J, Grillari-Voglauer R: hTERT alone immortalizes epithelial cells of renal proximal tubules without changing their functional characteristics. Am J Physiol Renal Physiol 2008, 295:F1365-F1375.

119. Orosz DE, Woost PG, Kolb RJ, Finesilver MB, Jin W, Frisa PS, Choo CK, Yau CF, Chan KW, Resnick MI, Douglas JG, Edwards JC, Jacobberger JW, Hopfer U: Growth, immortalization, and differentiation potential of normal adult human proximal tubule cells. In Vitro Cell Dev Biol Anim 2004, 40:22-34

120. Wilmer MJ, Saleem MA, Masereeuw R, Ni L, van der Velden TJ, Russel FG, Mathieson PW, Monnens LA, van den Heuvel LP, Levtchenko EN: Novel conditionally immortalized human proximal tubule cell line expressing functional influx and efflux transporters. Cell Tissue Res 2010, 339:449-457.

121. Chassin C, Bens M, Vandewalle A: Transimmortalized proximal tubule and collecting duct cell lines derived from the kidneys of transgenic mice. Cell Biol Toxicol 2007, 23:257-266.

122. Kim D, Dressler GR: Nephrogenic factors promote differentiation of mouse embryonic stem cells into renal epithelia. J Am Soc Nephrol 2005, 16:3527-3534

123. Batchelder CA, Lee CC, Matsell DG, Yoder MC, Tarantal AF: Renal ontogeny in the rhesus monkey (Macaca mulatta) and directed differentiation of human embryonic stem cells towards kidney precursors. Differentiation 2009, 78:45-56

124. Carroll TJ, Park JS, Hayashi S, Majumdar A, McMahon AP: Wnt9b plays a central role in the regulation of mesenchymal to epithelial transitions underlying organogenesis of the mammalian urogenital system. Dev Cell 2005, 9:283-292.

125. Park JS, Valerius MT, McMahon AP: Wnt/B-catenin signaling regulates nephron induction during mouse kidney development. Development 2007, 134:2533-2539.

126. Benzing T, Simons $M$, Walz $G$ : Wnt signaling in polycystic kidney disease. J Am Soc Nephrol 2007, 18:1389-1398.

127. Yokoo T, Fukui A, Ohashi T, Miyazaki Y, Utsunomiya Y, Kawamura T, Hosoya T, Okabe M, Kobayashi E: Xenobiotic kidney organogenesis from human mesenchymal stem cells using a growing rodent embryo. J Am Soc Nephrol 2006, 17:1026-1034.

128. Yokoo T, Ohashi T, Shen JS, Sakurai K, Miyazaki Y, Utsunomiya Y, Takahashi M, Terada Y, Eto Y, Kawamura T, Osumi N, Hosoya T: Human mesenchymal stem cells in rodent whole-embryo culture are reprogrammed to contribute to kidney tissues. Proc Natl Acad Sci USA 2005, 102:3296-3300

129. Baer PC, Bereiter-Hahn J, Missler C, Brzoska M, Schubert R, Gauer S, Geiger $\mathrm{H}$ : Conditioned medium from renal tubular epithelial cells initiates differentiation of human mesenchymal stem cells. Cell Prolif 2009, 42:29-37.

130. Fusaki N, Ban H, Nishiyama A, Saeki K, Hasegawa M: Efficient induction of transgene-free human pluripotent stem cells using a vector based on Sendai virus, an RNA virus that does not integrate into the host genome. Proc Jpn Acad Ser B Phys Biol Sci 2009, 85:348-362.

131. Jia F, Wilson KD, Sun N, Gupta DM, Huang M, Li Z, Panetta NJ, Chen ZY, Robbins RC, Kay MA, Longaker MT, Wu JC: A nonviral minicircle vector for deriving human iPS cells. Nat Methods 7:197-199.

132. Marchetto MC, Yeo GW, Kainohana O, Marsala M, Gage FH, Muotri AR: Transcriptional signature and memory retention of human-induced pluripotent stem cells. PLoS One 2009, 4:e7076.

133. Yusa K, Rad R, Takeda J, Bradley A: Generation of transgene-free induced pluripotent mouse stem cells by the piggyBac transposon. Nat Methods 2009, 6:363-369.

134. Yu J, Hu K, Smuga-Otto K, Tian S, Stewart R, Slukvin II, Thomson JA: Human induced pluripotent stem cells free of vector and transgene sequences. Science 2009, 324:797-801.

135. Ronco C, Ballestri M, Cappelli G: Dialysis membranes in convective treatments. Nephrol Dial Transplant 2000, 15(Suppl 2):31-36.

136. Li DF, Chung T-S, Wang R, Liu Y: Fabrication of fluoropolyimide/ polyethersulfone (PES) dual-layer asymmetric hollow fiber membranes for gas separation. J Membr Sci 2002, 198:211-223.

137. Yang Q, Wang KY, Chung T-S: Dual-layer hollow fibers with enhanced flux as novel forward osmosis membranes for water production. Environ Sci Technol 2009, 43:2800-2805.

138. Fissell WH, Manley S, Westover A, Humes HD, Fleischman AJ, Roy S: Differentiated growth of human renal tubule cells on thin-film and nanostructured materials. ASAIO J 2006, 52:221-227.

139. Kanani DM, Fissell WH, Roy S, Dubnisheva A, Fleischman A, Zydney AL: Permeability-selectivity analysis for ultrafiltration: effect of pore geometry. J Memb Sci 2010, 349:405.

140. Fissell WH, Fleischman AJ, Humes HD, Roy S: Development of continuous implantable renal replacement: past and future. Transl Res 2007, 150:327-336.

141. Fissell WH, Roy S: The implantable artificial kidney. Semin Dial 2009, 22:665-670.

142. Minuth WW, Schumacher K, Strehl R: Renal epithelia in long term gradient culture for biomaterial testing and tissue engineering. Biomed Mater Eng 2005, 15:51-63.

143. Minuth WW, Strehl R: Technical and theoretical considerations about gradient perfusion culture for epithelia used in tissue engineering, biomaterial testing and pharmaceutical research. Biomed Mater 2007, 2: R1-R11.

144. Minuth WW, Strehl R, Schumacher K, de Vries U: Long term culture of epithelia in a continuous fluid gradient for biomaterial testing and tissue engineering. J Biomater Sci Polym Ed 2001, 12:353-365.

doi:10.1186/1755-1536-3-14

Cite this article as: Tasnim et al: Achievements and challenges in bioartificial kidney development. Fibrogenesis \& Tissue Repair 2010 3:14. 